\title{
DRY EXTRACT OF BLACK RICE (ORYZA SATIVA L.) AS ANTIOXIDANT IN THE FORM OF FUNCTIONAL DRINK
}

\author{
ERLINDHA GANGGA*, QURRATUN AINI
}

\section{Department of Fakultas Farmasi Universitas Pancasila, Jakarta, Indonesia. Email: erlin_gens@yahoo.com}

Received: 07 March 2018, Revised and Accepted: 25 March 2018

\begin{abstract}
Objective: Based on previous research, black rice (Oryza sativa L.) has been proven to have antioxidant activity which is classified in the very strong category, approximately $41.5 \mathrm{bpj}$. this The aim of this study was to produce antioxidant functional drink.

Methods: Simplicia powder prepared from black rice (O. sativa L.) sample by extracting with $70 \%$ ethanol solvent using kinetic maceration, followed by phytochemical screening, determination of extract quality, drying extract with freeze-drying method, then dry extract obtained used to produce functional drinks on which evaluation and antioxidant activity test carried out. The antioxidant activity test used in this research was DPPH-free radical scavenging method.

Results: Screening result showed that both simplicia and extract contain flavonoid compounds, saponins, tannins, steroids, and triterpenoids. Result from dried extract quality determination shown to be thick consistency, has blackish-purple color, has specific aroma and bitter, water-soluble extract content of 59.04\%; ethanol-soluble extract content of $69.77 \%$; moisture content of 7.65\%; loss on drying $9.40 \%$; total ash content of 5.17\%; acidinsoluble ash content of $0.84 \%$; water-soluble ash content $4.15 \%$; and residual solvent $0.44 \%$. Pb and Cd metal contamination were 1.1994 mg/kg and $0.0905 \mathrm{mg} / \mathrm{kg}$, respectively. Total plate count microbial contamination TNTC and the number of yeast and mold found to be $0.0387 \times 10^{3}$ colony $/ \mathrm{g}$. Evaluation test of functional drinks with powder type and found to be blackish-purple, and specific aroma, and total plate count microbial contamination was $0.310 \times 10^{3}$ colony $/ g$, and the number of yeast and mold found was $0.6997 \times 10^{2}$ colony/g. Result of IC $_{50}$ antioxidant activity of viscous extract was $37.5587 \mathrm{bpj}$; dried extract was $231.0101 \mathrm{bpj}$; dried extract (distilled water) was $44.7412 \mathrm{bpj}$; and functional drinks were $46.3594 \mathrm{bpj}$.
\end{abstract}

Conclusion: Thus, results suggest that dried black rice's extract and functional drink produced found to have very strong antioxidant activity.

Keywords: Black rice, Antioxidant, Functional drinks, DPPH.

(C) 2018 The Authors. Published by Innovare Academic Sciences Pvt Ltd. This is an open access article under the CC BY license (http://creativecommons. org/licenses/by/4. 0/) DOI: http://dx.doi.org/10.22159/ajpcr.2018.v11s1.26597

\section{INTRODUCTION}

Antioxidant is a compound which could inhibit or prevent oxidation process caused by free radical [1]. Synthetic antioxidants such as Butil Hidroksi Anisol and Butil Hidroksi Toluene are very effective in preventing oxidation process. However, synthetic antioxidant can cause disruption on the liver and affects the function of enzymes in the liver [2]. The concern about the side effects of synthetic antioxidant makes natural antioxidants a viable alternative.

Rice is a staple food consumed by most Asian countries, especially in Indonesia. Color pigments on the outer layer of rice or aleurone from black rice have been reported to contain anthocyanin compounds.

Anthocyanin is one of the secondary metabolite compounds that belong to the class of flavonoids that have many uses and are found in many types of plants. Anthocyanin compounds acting as antioxidants and free radical catchers, thereby contributing to the prevention of degenerative diseases [4].

Adrian Baitairiza's research (2014) used DPPH-free radical damping method to conduct antioxidant activity test in vitro on extract of black rice (Oryza sativa L.), and the result showed that black rice extract has $\mathrm{IC}_{50}$ value of 41.5 bpj [5]. Therefore, this study aimed at making

functional antioxidant drinks from dry extracts of black rice that could quench thirst, healthy, practical, and consumable by the community. Functional drinks are beverages that contain elements of nutrients or non-nutrients and if consumed could provide beneficial effect on health. Functional drinks are a type of food or food product that has functional features and plays a role in protection, prevention, treatment of disease, improve body functions, and prevent aging [6].
The aim of this study was to obtain data on antioxidant activity from ethanol condensed extract $70 \%$, dry extract of black rice, and black rice water extract. To produce a functional beverage that has antioxidant activity from dry extract of black rice ethanol $70 \%$ and water extract.

\section{MATERIALS AND METHODS}

\section{Materials}

Black rice (O. sativa L.), sodium benzoate, ethanol 70\%, distilled water, chloroform, 95\% ethanol, 30\% ammonia, hydrochloric acid, Mayer reagent, Dragendorff's reagent, concentrated hydrochloric acid, Mg, amyl alcohol, iron (III) chloride $1 \%$, sodium hydroxide $1 \mathrm{~N}$, ethers pa, acetic acid anhydrous, concentrated sulfuric acid, 10\% ammonia, alcohol, sulfuric acid $\mathrm{P}, 10 \%$ nitric acid, sodium acetate $\mathrm{P}$, potato dextrose agar hatchery, nutrient agar, methanol, DPPH.

\section{Equipment}

Glasswares, blender, rotary vacuum, microanalytic scale, micropipette, incubator, ultraviolet-visible (Shimadzu 1700) spectrophotometer, atomic absorption spectrophotometer, cuvette, porcelain crucible, shallow dish, weighing bottle, desiccator, kiln, oven, Petri dish, filter paper, ash-free filter paper, freeze dryer.

\section{Steps of research}

\section{Preparation of black rice extract}

Black rice extract was made by kinetic maceration using $70 \%$ ethanol. As much as $2000 \mathrm{~g}$ of black rice was macerated with $70 \%$ ethanol and $4 \mathrm{~L}$ of water until all the simplifications were submerged, then the simplicia was soaked for $24 \mathrm{~h}$. The filtrate was then filtered and collected by repeating maceration process until it was perfectly extracted, the extract was collected together and then thickened with 


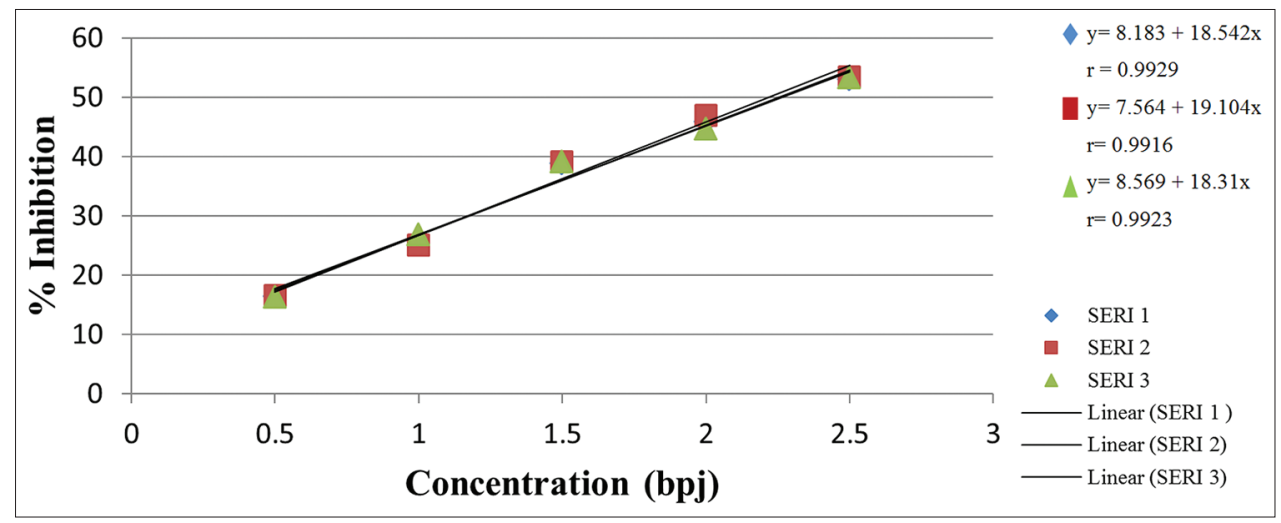

Fig. 1: Relation between concentration $(x)$ and $\%$ inhibition $(y)$ on BP Vitamin C

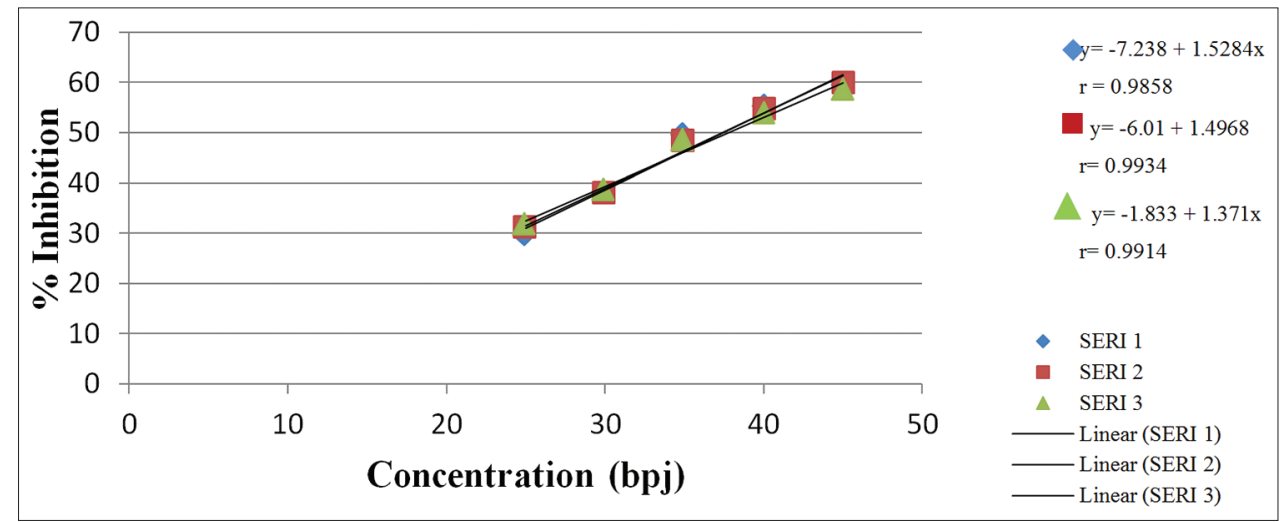

Fig. 2: Relation between concentration (x) and \% inhibition (y) on thick $70 \%$ ethanol extract black rice

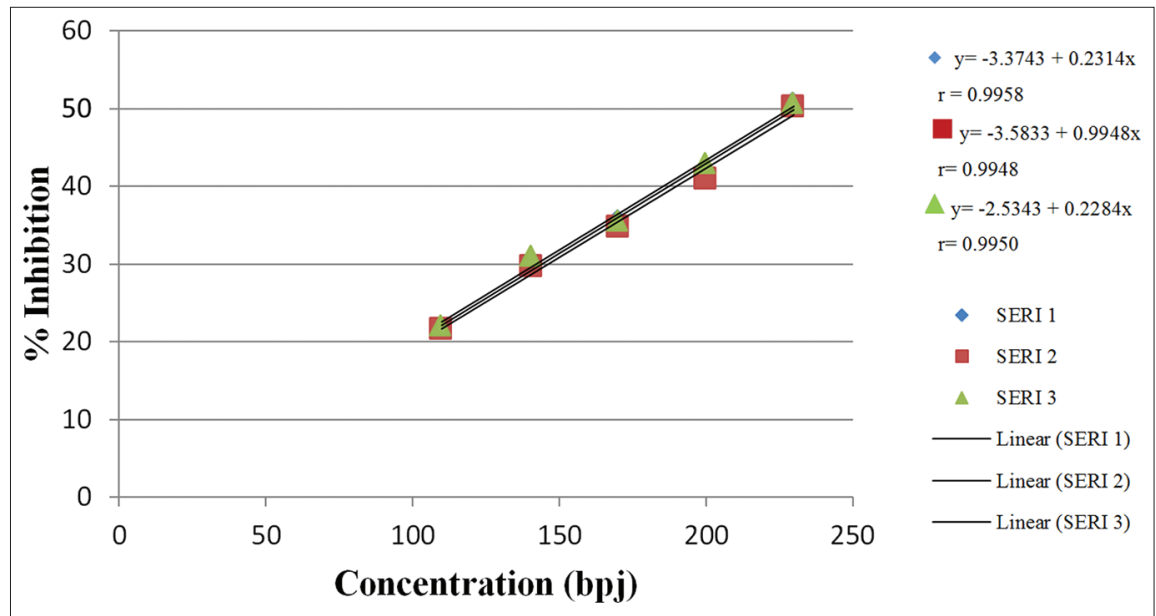

Fig. 3: Relation between concentration $(x)$ and $\%$ inhibition $(y)$ on dry black rice extract

vacuum rotary evaporator, and thick extract was obtained. Thick extract was undergone freeze-drying process. One sachet of functional drink formula was made of $4 \mathrm{~g}$ of dried extract of black rice, $1 \mathrm{~g}$ of red ginger powder, and $5 \mathrm{mg}$ of sodium benzoate.

\section{Phytochemical screening}

The phytochemical analysis of black rice extract has been performed to find the presence of major secondary metabolites such as flavonoids, tannins, saponins, steroid, and triterpenoid.

\section{Extract quality parameter determination}

Specific parameters determination

Organoleptic inspection, determination of dissolved compounds in water, determination of dissolved compounds in ethanol.
Non-specific parameters determination

Examination loss on drying, water content, total ash, acid not soluble ash content, residual solvents, heavy metal contaminants ( $\mathrm{Pb}$ and $\mathrm{Cd}$ ), and examination of microbial contamination.

\section{Antioxidant activity test}

About 70\% ethanol condensed extract, dried extract, dried extract (pure water solvent), and functional beverage of black rice.

Into each of the test solvent and the comparative aqueous solution (positive control) was added $1 \mathrm{ml}$ of $0.4 \mathrm{mM}$ DPPH solution and methanol proanalysis up to $5.0 \mathrm{~mL}$, then homogenized. The DPPH solution was added to the blank solution, test solution, and comparative solution (positive control), then immediately 


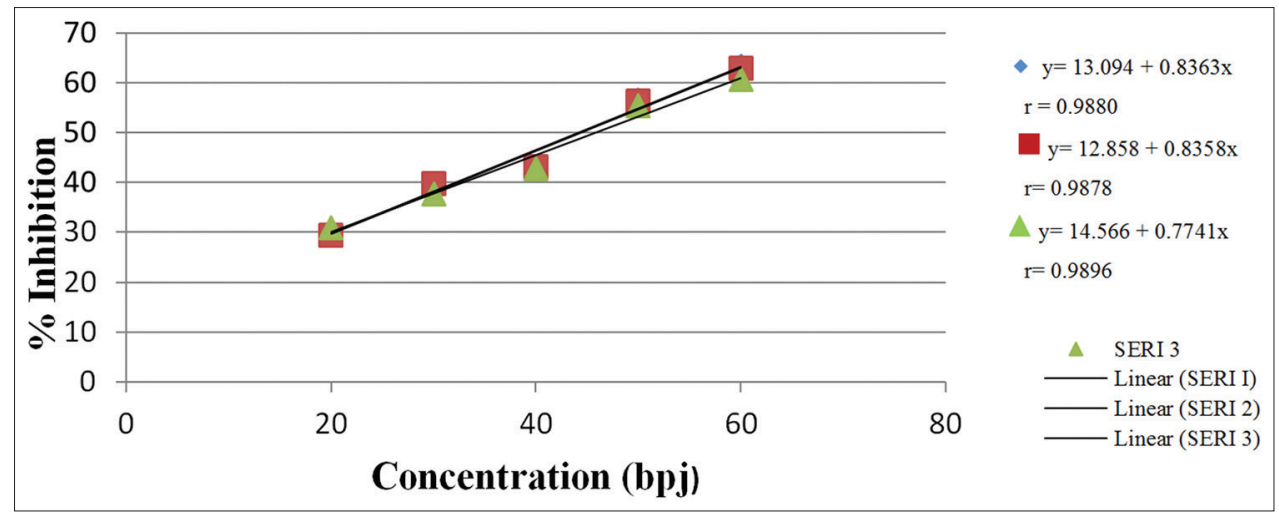

Fig. 4: Relation between concentration $(x)$ and $\%$ inhibition $(y)$ on dry black rice extract (pure water solvent)

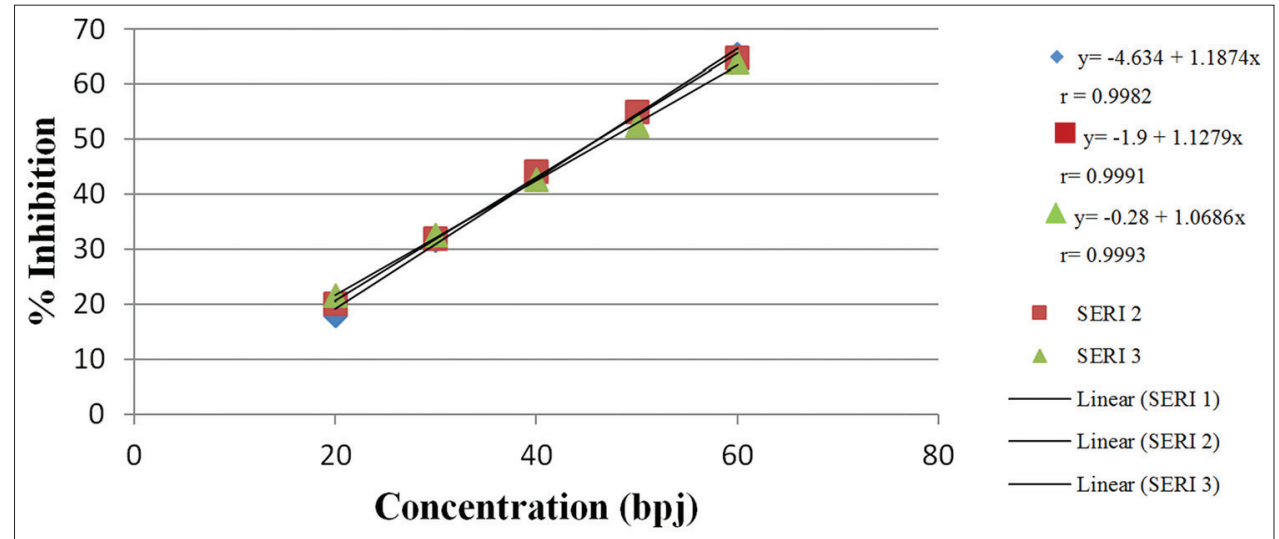

Fig. 5: Relation between concentration (x) and \% inhibition (y) on functional drink black rice extract

Table 1: DER native and black rice $70 \%$ and ethanol extract immersion

\begin{tabular}{lllll}
\hline Material & Simplicia (g) & Extract amount (g) & DER native & Rendement (\%) \\
\hline Black rice & 2009.3 & 83.2631 & 24.1319 & 4.14 \\
\hline
\end{tabular}

Table 2: Phytochemical filtering result for powder and $\mathbf{7 0 \%}$ ethanol extract black rice

\begin{tabular}{llll}
\hline No & Phytochemical filtering & Powder & Extract \\
\hline 1 & Alkaloid & - & - \\
2 & Flavonoid & + & + \\
3 & Saponine & + & + \\
4 & Tanin galat & + & + \\
& Tanin catecuat & + & + \\
5 & Quinone & - & - \\
6 & Steroid & + & + \\
7 & Triterpenoid & + & + \\
8 & Olive Oil & - & - \\
9 & Cumarin & - & - \\
\hline +: Positive reaction, -: Negative reaction & &
\end{tabular}

incubated for $30 \mathrm{~min}$ at $37^{\circ} \mathrm{C}$, then uptake test was done at $516.5 \mathrm{~nm}$ wavelength.

Antioxidant activity calculation

Formula for calculating free radical immersion (\%)

Inhibition $=\frac{\text { blanc } \text { absorption-sample absorbtion }}{\text { blanc bsorption }} \times 100 \%$

Next, $\mathrm{IC}_{50}$ calculation is using linear regression $\mathrm{y}=\mathrm{a}+\mathrm{bx}$. $\mathrm{IC}_{50}$ stated in $\mathrm{x}$.

$\mathrm{IC}_{50}$ (inhibition concentration 50) is antioxidant concentration (mg/L) which could inhibit $50 \%$ free radical.

\section{RESULTS AND DISCUSSION}

Preparation of $\mathbf{7 0 \%}$ ethanol extract black rice

Phytochemical screening

Secondary metabolite content test was done against powder and ethanol extract $70 \%$ black rice. The results of phytochemical screening of powders and extracts can be seen in Table 2 and in Appendix 10.

Extract quality parameter determination

Specific parameter

a. Extract identification

Extract identification result can be seen in Table 3 .

b. Organoleptic

Organoleptic extract result can be seen in Table 4 .

Making of black rice dry extract

Dry powder making was done with freeze-drying method which was carried out in "Herbarium Bogoriense" Botanical Field of Biology Research Center-LIPI, Cibinong.

Functional drink formula

Antioxidant test result from $5 \mathrm{~g}$ of functional drinks shows antioxidant activity of $\mathrm{IC}_{50} 46.36 \mathrm{bpj}$. Based on this result, the functional drinks were made of $4 \mathrm{~g}$ of dried extract of black rice, $1 \mathrm{~g}$ of red ginger powder, and $5 \mathrm{mg}$ of sodium benzoate.

\section{Antioxidant activity test}

Based on the data above, the antioxidant activity test on ethanol extract $70 \%$ of black rice, dry black rice extract, dry extract of black rice (pure 
Table 3: Identity determination result of $70 \%$ ethanol extract black rice

\begin{tabular}{lll}
\hline No. & Extract identity & Test result \\
\hline 1 & Extract name & O. sativa fructus extractum spissum \\
2 & Latin name of extract & O. sativa L. \\
3 & Part of plant used & Fructus \\
4 & Indonesian name of & Beras hitam \\
& the plant & \\
\hline O. sativa: Oryza sativa &
\end{tabular}

Table 4: Result of extract organoleptic test

\begin{tabular}{lll}
\hline No. & Organoleptik & Test result \\
\hline 1 & Texture & Thick extract \\
2 & Color & Dark purple \\
3 & Smell & Specific aroma \\
4 & Taste & Bitter \\
\hline
\end{tabular}

Table 5: Antioxidant activity test result

\begin{tabular}{ll}
\hline Sample & IC $_{\mathbf{5 0}}$ Value (bpj) \\
\hline BP Vitamin C & 2.2464 \\
Ethanol extract 70\% black rice & 37.5587 \\
Black rice dry extract & 231.0101 \\
Black rice dry extract (pure water solvent) & 44.7412 \\
Functional drink black rice dry extract & 46.3594 \\
(red ginger powder addition and sodium & \\
benzoic) & \\
\hline
\end{tabular}

Table 6: Organoleptic test result on functional drink

\begin{tabular}{lll}
\hline No. & Organoleptic & Test result \\
\hline 1 & Shape & Powder \\
2 & Color & Black \\
3 & Odor & Distinctive aroma \\
\hline
\end{tabular}

Table 7: Microbe contamination test result

\begin{tabular}{llll}
\hline No. & Parameter & Result & $\begin{array}{l}\text { BPOM requirement } \\
\text { (colony/g sample) }\end{array}$ \\
\hline 1 & $\begin{array}{l}\text { Total plat } \\
\text { account (ALT) }\end{array}$ & $0.310 \times 10^{3}$ & $\leq 3 \times 10^{3}$ \\
2 & AKK & $0.6997 \times 10^{2}$ & $\leq 1 \times 10^{2}$ \\
\hline
\end{tabular}

water solvent), and functional beverage of dry extract of black rice each yield $\mathrm{I}_{\mathrm{C} 5} 0$ value of $37.5587 \mathrm{bpj}, 231.0101 \mathrm{bpj}, 44.7412 \mathrm{bpj}$, and 46.3594 bpj. This suggests that the test substance has antioxidant activity. The presence of antioxidant activity is due to a class of secondary metabolite compounds such as flavonoids contained in ethanol extract $70 \%$ black rice. Flavonoid compounds can inhibit oxidation by giving $\mathrm{H}$ atoms that bind free radicals to produce more stable compounds.

The antioxidant activity of ethanol viscous extract of $70 \%$ black rice was weaker than the comparative standard of Vitamin $\mathrm{C}$ with $\mathrm{IC}_{50}$ value of $37.5587 \mathrm{bpj}$ but still showed very strong antioxidant properties. The results of black rice antioxidant activity in this study were stronger than the previous study which showed $\mathrm{IC}_{50}$ value of $41.5 \mathrm{bpj}$. This is due to the fact that this used ethanol $70 \%$ as a seeker so that flavonoid compounds can be perfectly seared.

The antioxidant activity of dry extract of black rice has a weaker $\mathrm{IC}_{50}$ compared to the ethanol condensed extract of $70 \%$ black rice, which is $231.0101 \mathrm{bpj}$. This may be due to the addition of maltodextrin filler in the freeze-drying process so that maltodextrin coated the viscous extract and caused the test sample was not extracted perfectly. The reason for selecting maltodextrin as a filler in the freeze-drying process is it is a safe, relatively inexpensive, easy-to-use, more often used filler in the food industry than other fillers.

In the test of functional drink made from dry extract of black rice (using pure water as solvent of test substance) with $\mathrm{IC}_{50}$ equal to 44.7412 bpj, red ginger (as aroma and flavor enhancer) and sodium benzoate as preserver were added. After this, we obtained $\mathrm{IC}_{50}$ value of 46.3594 bpj which shows very strong antioxidant properties. This decrease in antioxidant activity is due to the addition of red ginger and sodium benzoate. Red ginger cannot act as antioxidant because it was made not in extract form, so the compounds that have activity as an antioxidant is not extracted during antioxidant activity testing.

\section{Functional drink evaluation}

Organoleptic

Organoleptic test result on functional drink dry black rice extract can be seen in Table 6 .

Organoleptic examination is one of the specific parameters determined using the five senses and aims to provide early recognition as well as signify the hallmark of functional beverage of dried extract of black rice in form, color, and odor. Organoleptic examination results showed a dry extract of black rice in the form of powder, black with distinctive aroma.

\section{Microbe contamination}

Microbe contamination test result on functional drink dry black rice extract can be seen in Table 7 .

Testing of microbial contamination is done to find out the number of microorganisms contained in functional drinks of black dry rice extract, which in excess amount can be harmful to health. Functional drinks of dried extracts of black rice obtained should not contain pathogenic or non-pathogenic microbes beyond predetermined limits.

The results of the contamination test shown in Table 7 still meet the requirements stipulated by the Food and Drug Supervisory Agency (BPOM) on the Determination of the Maximum Limit of Microbial and Chemical Feeding in Foods which are for ALT $\leq 3 \times 10^{3}$ and for AKK $\leq 1 \times 10^{2}$. The presence of microbes in the extract can occur during the processing of drinks that are less hygienic, but the amount of contamination contained in the drink is still within the maximum limit of microbial contamination.

\section{CONCLUSION}

1. About $70 \%$ ethanol condensed extract and dry extract of black rice with maltodextrin filler had antioxidant activity of $37.55 \mathrm{bpj}$ and 231.38 bpj, respectively.

2. Functional drinks extract of dried black rice with the addition of red ginger is a very powerful antioxidant because it has an $\mathrm{IC}_{50}$ value of $46.36 \mathrm{bpj}$.

\section{REFERENCES}

1. Tan P, Maluyu N, Kawengian S. Description of activity and stability of antioxidant black rice extract (Oryza sativa L.) in enrekang cultivar South Sulawesi. J e-Biomed 2016;4:184

2. Baitariza A, Darijanto ST, Pamudji JS, Fidrianny I. Formulation and evaluation of the black rice extract extracting microemulsy (Oryza sativa L). Int J Pet Sci Technol 2014; 16.

3. Sampoerno, Fardiaz D. Policy and development of functional food supplement in Indonesia. Prosding National Traditional Food Seminars Base for Functional Food Industry and Supplements. Center for Traditional Food Studies. Bogor: Bogor Agricultural University, 2001.

4. Black Rice. Available from: http://www.fimandadi.com. [Last accessed on 2016 Jul 31].

5. Ministry of Health of the Republic of Indonesia. Medical Material. Vol. II. Jakarta: Ministry of Health RI; 1978. p. 113-5.

6. Syamsuhidayat SS, Hutapea JR. Inventory of Indonesian Medicinal Plants. Vol. I. Jakarta: Health Research and Development Agency 
Ministry of Health Rebublik Indonesia; 1991. p. 596.

7. Directorate General of Drug and Food Control. Ministry of Health of the Republic of Indonesia Indonesian Pharmacope. $5^{\text {th }}$ ed. Jakarta: Directorate General of Drug and Food Control; 2014. p. 905.

8. Winarsih H. Natural Antioxidant and Free Radical Potential and its Application in Health. Yogyakarta: Kanisius; 2007. p. 20-77.

9. Ministry of Health of the Republic of Indonesia. Indonesian Medical Material. $6^{\text {th }}$ ed. Jakarta: Directorate General of Drug and Food Control; 1995. p. 10.

10. Ministry of Health of the Republic of Indonesia. Indonesian Pharmacope. $5^{\text {th }}$ ed. Jakarta: Directorate General of Drug and Food Control; 2014. p. 42

11. Ministry of Health of the Republic of Indonesia. Handbook of Extract Technology. Jakarta: Directorate General of Drug and Food Control; 2000. p. 13-4

12. Freeze Drying Technology: For Better Quality and Flavor of Dried Products; 2012. Available from: . [Last accessed on $2016 \mathrm{Ju}$

13. Bhatiyadi P. Freeze drying technology: For better quality and flavor of dried products. Foodrev Indones 2013;8:53-4

14. Farnsworth NR. Biological and phytochemical screening of plants.
J Pharm Sci 1966;55:225-76.

15. Sunarni T, Pramono S, Asmah R. Flavonoid antioxidant radical catcher from leaves of boiler (Stelechocarpus burahol (B1.) Hook f. \& Th). Fam Indones Mag 2007;18:112.

16. Komayaharti A, Paryanti D. Betel Leaf Extract as an Antioxidant in Coconut Oil. Semarang: Faculty of Engineering Department of Chemical Engineering Diponegoro University; 2009. p. 1.

17. Nuranda A, Saleh C, Yusuf B. Potential Ciplukan Plant (Physalis angulata Linn.) As a Natural Antioxidant. Samarinda: Mulawarman University; 2016. p. 5.

18. Tan P, Maluyu N, Kawengian S. Description of activity and stability of antioxidant black rice extract (Oryza sativa L.) in enrekang cultivar South Sulawesi. J e-Biomed 2016;4:184.

19. Baitariza A, Darijanto ST, Pamudji JS, Fidrianny I. Formulation and evaluation of the black rice extract extracting microemulsy (Oryza sativa L). Int J Pet Sci Technol 2014;:16.

20. Sampoerno, Fardiaz D. Policy and development of functional food supplement in Indonesia. Prosding National Traditional Food Seminars Base for Functional Food Industry and Supplements. Center for Traditional Food Studies. Bogor: Bogor Agricultural University, 2001. 